Vilkitski's North-East Passage, 1914-15

Author(s): L. M. Starokadomski and O. J. Cattley

Source: The Geographical Journal, Vol. 54, No. 6 (Dec., 1919), pp. 367-375

Published by: geographicalj

Stable URL: http://www.jstor.org/stable/1779414

Accessed: 23-06-2016 10:06 UTC

Your use of the JSTOR archive indicates your acceptance of the Terms \& Conditions of Use, available at

http://about.jstor.org/terms

JSTOR is a not-for-profit service that helps scholars, researchers, and students discover, use, and build upon a wide range of content in a trusted digital archive. We use information technology and tools to increase productivity and facilitate new forms of scholarship. For more information about JSTOR, please contact support@jstor.org.

The Royal Geographical Society (with the Institute of British Geographers), Wiley are collaborating with JSTOR to digitize, preserve and extend access to The Geographical Journal 
shown as complete, may perhaps retain territory lying south of the line from Pec eastward to the Klagenfurt area (see Fournal, p. 293). Belgium and Holland are shown as still incomplete owing to the possibility of mutual agreement for exchange of territory.

\section{Note on the Terminology of the Treaties.}

In an article on the New Boundaries of Austria published in the November Fournal, we criticized the use of the term 'delimitation' in such phrases as "a line to be delimited on the ground," and contended that this is demarcation, not delimitation. A correspondent who should be especially well informed replies that "the final 'delimitation' will be the definition, in words, made out by the Boundary Commission, after a visit to the ground." With all respect, we would maintain that the term proper to this last process is 'description,' and that the three steps in the settlement of a boundary are best described by the terms delimitation in the Treaty, demarcation on the ground, and description in the report of the Commission.

Our correspondent sends also a note on the method of defining distance to which we referred: "about 4 I/2 kilometres upstream from the Pressburg bridge." Overlooking the fact that the English text as printed means four half-kilometres, rather than $4 \frac{1}{2}$ kilometres, he raises the interesting point that 'about $4 \frac{1}{2}$ ' is right, as the point is to be chosen between 4 and 5 kilometres from Pressburg, not between $4^{*} 4$ and $4^{\circ} 6$, as might be assumed if it were described as about 4.5 . This is an inconvenience of the decimal system which is worth considering. But if the objection is well founded, it applies hundredfold to the French text, ' 4 kilomètres 500 environ,' which would allow a range of choice within only I metre: unless indeed one takes the refined point that the word 'about' allows a range of $\mathrm{I}$ unit in the last significant figure, in which case 'about $4.500^{\prime}$ ' means between 4.4 and $4^{\circ} 6$; while about I roo metres means between rooo and $\mathbf{2 0 0}$. It is doubtful if so much precision can be given to the designedly vague word '.about.'

A. R. H.

\section{VILKITSKI'S NORTH-EAST PASSAGE, I9I4-I5}

The following is abridged from a narrative of the above voyage by L.M. Starokadomski, published in Russian at Petrograd in 1916, but which has only lately found its way to this country. We are indebted to Mr. O. F. Cattley, a Fellow of the Society, for a translation in full of the Narrative, which has been placed in the Library.

C $\mathrm{HE}$ voyage of the Russian ice-breakers Taimuir and Vaigach in 19I3

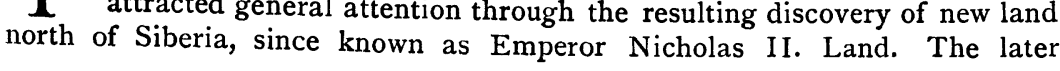


voyage of the same vessels is no less worthy of notice, as they were the first to accomplish the voyage from the Pacific to Archangel by way of the Arctic Ocean. The voyage, begun on 24 June 1914 and completed on 3 September 1915 , yielded much material in various branches of science through observations taken en route or during the enforced wintering in high latitudes. As previously, the Taimuir was under the command of Commander B.A. Vilkitski, whilst Commander P. A. Novopashennoi was captain of the Vaigach.* The main obiect was to cross the Arctic Ocean from the Pacific to the Atlantic, but hydrographic surveys were to be carried out so far as possible during the voyage. Each vessel was provisioned for a year and a half, and was provided with the necessary equipment for ice-navigation and scientific research, including a hydro-aeroplane. In order to replenish supplies at the last possible moment, the transport Tobol, under the command of Lieut. M. N. Shadenoff, was detailed to accompany the other ships as far as the edge of the ice.

After touching at Hakodate and passing through the Sangar Straits, where soundings were made and samples of sea-water collected, the ships proceeded to Petropavlovsk, where they found the British cruiser Newcastle, sent thither for the purpose of placing a memorial stone over the grave of Captain Clerke, the companion of Captain Cook on his last voyage. It was found impossible to exactly locate the grave, and the monument-a small stone pyramid with suitable inscription-was therefore placed near the church, not far from the memorial of another famous navigator, Bering. At the harbour in Providence Bay the Tobol was met with, and, supplies having been taken on board, the Taimuir sailed for Nome, where it was expected to meet Captain Bartlett of the ill-fated Karluk, whose crew the expedition had been asked by the Canadian Government to succour. He had, however, already sailed in the American revenue cutter Bear. At Nome news was received of the outbreak of the European war, but when, on reaching the wireless station at Novo Mariinsk at the mouth of the Anadyr, the officers placed themselves at the disposal of the authorities at Petrograd, the order came to continue the expedition. On August I the Taimuir rounded Cape Deshneff and entered the Arctic Ocean, meeting the Tobol in Koliuchin Bay in the evening of the same day. The Tobol had parted from the Vaigach on July 25 , and had since had no news of her. Both ships had encountered occasional patches of broken ice, and in Koliuchin Bay the Tobol had been torn from her anchors by a floe. During the night of August 2-3 a wireless message stated that the Vaigach was icebound 15 miles east of Cape Hawai on Wrangel Island. The temperature at this time ranged between $+3^{\circ}$ and $+6^{\circ} \mathrm{C}$., with a light breeze from the north. After taking soundings and carrying out survey work, the Taimuir sailed for Wrangel Island and, forcing her way into the ice, came to a stand some ro miles from the Vaigach, which was unable to move because the end of a large piece of ice had got under her propeller; but this was eventually cut away. As it was hopeless to reach Wrangel Island from the south or east the attempt to relieve the crew of the Karluk had perforce to be abandoned. Both ships returned to Koliuchin Bay on August 6-the Vaigach slightly crushed and with a blade of her propeller lost.

After finally taking in coal and water and sending the last letters on board the Toliol, both vessels steamed out of the bay, ready for the long voyage. After passing Cape Billings a renewed attempt was made to reach Wrangel Island, this time from the west, but repeated attempts proved unavailing. No

* The writer of the narrative, L. M. Starokadomski, sailed as medical officer in the Taimuir. 
vessel has ever succeeded in passing this way, where it seems that some barrier must hold the ice-possibly the problematical land reported by Andreyeff in 1764, which, if it exists, would go far to explain the distribution of the ice in the eastern part of the Siberian Arctic Sea. On a large ice-floe, from which a bright light was seen at night, a party of twenty Chukchis were met with; they had taken refuge there and built a large fire of driftwood. They made for the Taimuir, hoping to be taken to land, but this was impossible. For the most part short and stocky, their leader stood out prominently-an old man of commanding presence, more like an American than a Chukchi or Eskimo.

Squalls with fog and some snow were now experienced, and on August II the temperature fell for the first time to below freezing-point, reaching $-4^{0}{ }_{2} \mathrm{C}$. in the evening. On the meridian of Chaun Bay the vessels parted company with the object of exploring as large an area as possible. The Vaigach steered or the Bear Islands, the Taimuir northward. The latter course would bisect the "forbidden" area which no ship had been able to cross, and which should contain Andreyeff's Land if it existed. Even the ice-breakers in the preceding year had been turned from their course by accumulations of heavy ice between Bennet and Wrangel islands. Again in I9I4 the Taimuir got entangled, and only reached comparatively open water after rounding the debated area, which therefore still remains unexplored. It would be interesting to discover what causes the ice to pile itself into impenetrable masses to the west of Wrangel Island. Amid constant squalls of snow and hail the Taimuir closed with General Vilkitski Island on August 24. It was covered with snow, broken only by crags of dark basalt. The flagstaff planted in I9I 3 still held firm, with some tattered remnants of the national flag. No life was to be seen apart from the walruses which sported about the ship. In I9I3, only a week earlier, the island was free from snow, fledglings of the three-toed gull and other birds were still unable to fly, and mosses and short grass were still green.

On nearing the Bear Islands the Vaigach encountered freshly formed pancake and scum ice, and on steering for the New Siberia Islands met with heavy ice. On receiving orders by wireless from the Taimuir she steered for Jeannette Island, with a view to charting it and if possible Henrietta Island also; but heavy ice compelled her to alter her course to west and south-west, and it was found that a current had carried her 30 miles to westward. She therefore proceeded to an arranged rendezvous at General Vilkitski Island, whence yet another new island was descried to the northward and approached for the purpose of taking astronomical observations and planting a flag. From a distance its heights gave the impression that there were two islands. The Taimuir, too, having completed the charting of General Vilkitski Island, forced her way through heavy ice to the northward of the new island, and joined her consort. This island, which lies in lat. $76^{\circ} 10^{\prime} \mathrm{N}$., long. $153^{\circ} \mathrm{E}$., is larger than General Vilkitski Island, having a circumference of about 20 miles. Its eastern side is high and abrupt, the northern and western shores are low, but at no great distance inland are the foothills of wide elevations which occupy the whole centre. Snow lay in the valleys, driftwood was seen on the low north shore, and traces of copper were observed in the rocks. Two varieties of gulls and one species of sandpiper were secured. There is a large lagoon on the north shore, the water of which pours from some height in cascades to the sea, but as it is salt, this must happen at the ebb only.

The Vaigach now set a course for the Taimuir peninsula, passing north of the New Siberia Islands for survey purposes. It was possible to pass close to 
Thaddeus and Kotelnoi, but the shallowness of the water hindered access to Figurin. The cruise lasted from August 14 to 18, and only on the 16th was ice encountered-a broken strip of floes. Between St. Samuel Islands and the mainland of Taimuir peninsula, however, the whole area was full of pack-ice. Threading her way through ice and lanes of water the Vaigach sighted, on August 19, the cairn erected on Cape Cheliuskin in I90I by Baron Toll's expedition in the Zaria. The Taimuir meanwhile had held on a more northerly course in order to determine the boundary of the ice-drift from the north. Bennett Island was sighted on August 15. It too was covered with more snow than even on 9 September 1913. No sign was seen of the supposed Sannikoff Land, which the fisherman of that name, and much later Baron Toll, claimed to have seen from Kotelnoi ; but owing to the transparency of the air and pronounced refraction on a summer day in the Arctic, it is possible that land lying much further north may occasionally be visible. From August 16 onwards ice was encountered, sometimes old ice in immense masses, and progress became difficult. Cloudy weather, fogs, and snow showers also made it difficult to fix the ship's position. At last on August 20 the Taimuir approached Cape Cheliuskin, and the commander went ashore with several men and examined the Zaria's cairn, which looked as if it had but recently been erected. Along the low foreshore colossal pieces of ice formed a continuous ice-wall round the promontory, and as in 1913 there had been no trace of ice-pack in this neighbourhood, it is probable that the upheaval took place during some storm in the summer of 1914. No vessel near the shore could have withstood the pressure of such ice. The party regained the ship with difficulty, having to drag the whaleboat for some distance over the ice. Whilst battling with the ice the Taimuir had not escaped injury, leaks being discovered owing to which part of the provisions had been damaged.

The Vaigach now succeeded in reaching Emperor Nicholas II. Land, but the Taimuir failed to force the ice-barrier and had to tie up to an ice-field. The greater part of the voyage -4700 miles from Vladivostok-had now been performed, and of the 1400 still remaining the first 300-from Cape Cheliuskin to the exit from the Nordenskiöld Archipelago-presented the greatest difficulties. Both Nansen and Baron Toll experienced much trouble here, and of three explorers only Nordenskiöld, in 1878, had crossed this zone without meeting with ice-obstructions. The Vaigach passed the south-east end of Emperor Nicholas II. Land and proceeded along the southern coast through a fairly wide channel of open water. Soundings registered depths of from 27 to 83 fathoms. The coast-line here trends south and falls rapidly, the mountains receding far inland. The south-western end was reached (apparently) in about lat. $77^{\circ} 50^{\prime}$ N., long. $99^{\circ}$ E., whence the Vaigach turned back, charting the coast and also passing along the western end of Tsarevich Alexei Island (not charted in 1913) and the west coast of an island lying between this and Emperor Nicholas II. Land. This last was discovered in 1913 by the author of the present narrative, and was named from him Starokadomski Island by Commander Vilkitski. Its length is about 6 miles. Meanwhile the Taimuir had become more or less ice-bound and drifted 14 miles to the east of Cape Cheliuskin, but at length forced a way through and joined the Vaigach. To the west nothing but solid ice was to be seen, from which the south-west wind would break off large pieces which floated eastward. At the south-west end of Nicholas II. Land the water shoaled to 20 fathoms and two huge icebergs were aground. Such had never been observed in the eastern part of the ocean, there being no glaciers there capable of producing them. Those now observed no 
doubt came from far, probably from Franz Josef Land. One seen in 1913 had grounded in 70 fathoms, and the shallowness of the eastern waters prevents them from being carried much beyond Cape Cheliuskin.

On August 22-23 the ships lay anchored to the ice near the land, and on the former day a nearly total eclipse of the moon was observed. A landing was effected under some difficulty, owing to the presence of a long strip of piled-up ice something like the wall near the Zaria's cairn. On the further side came first the shore ice, then a strip of shallow water across which the men had to be ferried singly in a punt. The low broken coast trends from the east coast mountains to the south-west cape, where it bends abruptly to the north. Inland is a range of large low hillocks receding into the distance. Near the south-west cape there is a single high mountain with flat top similar to the heights on the east coast. The ground is sand and tundra, the latter already frozen at the date of the visit. The tops of the hillocks were bare, but much snow lay in the hollows. On the abrupt shore-line outcrops of ore-bearing rocks were seen. The air temperature fell below $-3^{\circ} \mathrm{C}$.

From August 23 to September II constant efforts were made to force a passage, but by the latter date it became certain that the ships would be unable to move further that year. They were carried hither and thither amidst the ice, unable to move independently, and though a strong south-east wind might have cleared the southern coast of the Taimuir peninsula, no such desirable wind sprang up. In the course of their wanderings the ships touched both at the Axel Heiberg and the Fernley Islands, landings being effected and samples of ore collected from the south-west island of the latter group. No one had previously landed on either group. In endeavouring to force the ice-barrier the Taimuir got badly nipped between two large ice-fields : the hull was crushed in on the port side, seventy frame ribs were bent or broken so as to offer hardly any resistance in the event of another nip, and nine bulkheads were crumpled and cracked. The rudder chains also broke more than once. The Vaigach, which had tried to render assistance, only just escaped a similar experience. Owing to this mishap it was decided to get stores on deck in case of a forced abandonment of the ship.

During the night following a wireless station was heard operating, and a call elicited the reply from Sverdrup that the Eclipse expedition in search of Brussiloff and Russanoff was between Tillo and Markham Islands, having tried without success for three days to pass the former, which were distant 180 miles from where the ice-breakers lay at the time. The near neighbourhood of so experienced a leader as Sverdrup was a great stroke of luck, for, apart from its moral effect, it afforded the possibility of obtaining valuable advice for the threatened wintering, and also of wireless communication with the station in Yugor Strait, besides offering a possible refuge in the event of the abandonment of the ship.

On August 30 the Vaigach got into an open channel and reached King Oscar peninsula, but again encountered an ice barrier and was subjected to a rather severe nip; but though taking on a list she escaped serious damage. On September 2 the temperature sank to $-9^{\circ} \mathrm{C}$., and snow fell most of the day. Hopes were raised when a southerly wind blew, but though the ship got clear of the ice for a time, it was again encountered and progress was stopped. The temperature continued persistently below the freezing-point, the young ice was thickening and even beginning to pack, and eventually held the ship fast. The Taimuir too used every possible means, including blasting, putting out iceanchors, and warping, to pass from one water space to another, and so at least 
approach the mainland-she was distant therefrom about 5 miles-but all without success. The ship was caught in a tremendous stream of swiftly drifting ice-masses, colliding and grinding together, and preparations were made for leaving the ship. At last the motion ceased and the Taimuir lay at the edge of a huge ice-field, the Heiberg Islands being visible in the distance to the north-west. The ice-field itself was subjected to heavy pressure and began breaking up, while snow repeatedly blotted out all view. On the night of September 9 the crew slept in their clothes, supplies for three weeks being collected in a suitable place. The next day the ship started to drift to the south-west, and at last found a channel of open water along which she steamed under the land, but on September in a rapid fall of temperature to $-10^{\circ} \mathrm{C}$. caused young ice to form round the ship. She lay in 7 fathoms of water, about 2 miles from the shore of a broad bay-Dick's Bay of Nansen. Ultimately both ships were shifted somewhat, but only for very short distances. The winter quarters of the Taimuir were in $76^{\circ} 4 \mathrm{I}^{\prime} \mathrm{N}$. lat., $100^{\circ} 50^{\prime} \mathrm{E}$. long., and of the Vaigach $76^{\circ} 54^{\prime} \mathrm{N}$. lat., $100^{\circ}{ }_{1} 3^{\prime} \mathrm{E}$. long. They were 16 miles apart and Ioo miles from Cape Cheliuskin.

The Taimuir may be held to have gone into winter quarters on September II ; the Vaigach did not move independently after September 8. The Eclipse approached Cape Stelling on August 30, but on September 13 took advantage of a temporary movement of the ice and changed her position to near Cape Wilda. It may be recalled that the Zaria in I 900 was forced to go into winter quarters on September 13; the Fram worked her way across this region with great difficulty between August I4 and 29; and only the Vega got through in the first week of August, I878, without encountering obstacles of any importance.

From this time on constant wireless communication was maintained with the Eclipse, but the latter failed to get into touch with the station at Yugor Strait. Preparations for the winter were made on both ships. Two waggon-like boxes belonging to the hydro-aeroplane were taken ashore and converted into a store and rough shelter. A rationing scheme was drawn up which carried the party through the winter quite satisfactorily. Of the live stock shipped at Vladivostok much had been consumed or lost; but some of the young pigs had grown considerably and were the objects of especial care. Stacks of driftwood-of which there was not much-were made. On shore a considerable herd of reindeer was seen, with white partridges and fox tracks. Eider duck were still flying from the mainland in mid-September. A trip to investigate a high dark object standing up about 7 miles from the Taimuir, which had the semblance of a small ship with its masts cut away, proved it to be an enormous piece of old ice, its edge liberally plastered with clay. The engines of both ships were overhauled, but before this was finished the ice in which they lay was torn away and carried north, necessitating a refitting of the engines. By October 6 the Taimuir was 7 miles from the shore, the temperature at this time varying between $-10^{\circ}$ and $-17^{\circ} \mathrm{C}$. On board stoves were used for heating, two warm compartments being arranged, connected by a cold corridor. The cabins were lighted with pyro-naphtha lamps. Round the ship contrivances were rigged up to permit the taking of scientific observationsmeteorological, barometric, dredging for live specimens from the sea-bottom, determinations of the thickness of the ice and of the rise and fall of the water. A trip from one ship to the other was accomplished in a temperature of about $-28^{\circ} \mathrm{C}$. The Eclipse extended her wireless by means of a mast rigged up on the ice, but was not able to open regular communication with the civilised 
world until January, though before this a few sentences in Norwegian, probably emanating from the Inge station in North Spitsbergen, were picked up. In order to keep the party in health regular open-air exercise was arranged-walks, races, wrestling matches, etc.--and regular instruction was given in educational subjects, as well as lectures on popular subjects.

Three times during the long night the moon never left the heavens for from nine to ten consecutive days, and though there were consecutive days on which the moon never rose above the horizon, there remained the northern lights which helped to dispel the darkness, and Lieut. Evgenoff was never prevented from sending up a kite with meteorological instruments. On the other hand there were some days on which one could see nothing but his feet against the snow, all besides fading into a turbid white. Such a day occurred on the eve of the middle of the polar night, when the sun's altitude at noon was $-9 \frac{1}{4}^{\circ}$. A streak of pale light could then be seen above the clouds on the southern horizon. The sky was full of stars. On December 20 the Taimuir was photographed by moonlight with exposures of $\mathrm{I}$ hr. 20 mins. and I hr. $30 \mathrm{mins}$. Christmas and the New Year were observed with suitable ceremonies. On the opening of wireless communication messages were received from Petrograd conveying the good wishes of the Emperor, the Minister of Marine, and other functionaries. On January 29 the edge of the sun was seen as a splash of red through low light clouds, and a carnival, small play, and games, were held on the ice in honour of the occasion. In the beginning of February a small party from the Taimuir visited the Vaigach in $40^{\circ}$ of frost. On the 16 th the first death occurred-that of Lieut. A. N. Shokhoff of the Vaigach, who was buried on shore, a home-made wreath being placed by his comrades on his grave. In March another mound rose alongside it, the grave of fireman Ladonicheff, who died of appendicitis.

Early in March work was begun on repairs. The hydro-aeroplane was put together but did not prove a success. The engine was utilized for an aerosleigh, but by the time this had been made to work efficiently the thaw prevented its use. It was decided to construct a wireless station on Dickson Island in the Yenesei Gulf, and to make preparations for the possible wintering of the sixty people who would be remaining on the ships, after eighteen men from each ship, with three officers, had been transferred to the Eclipse. The Dickson Island station was organized successfully by P. G. Kushakoff, a member of Sedoft's expedition. The journey to the Eclipse was prepared for by the laying down of depôts with Sverdrup's aid. Mild weather came with April, and on the 4th a snow-bunting appeared as a precursor of spring. From the IIth onward the sun ceased to sink below the horizon. Although at first welcomed with delight, this is speedily followed by a feeling of irritability and fatigue, due to the disorganization of habits and the difficulty of obtaining refreshing sleep. Snow-blindness was provided against by improvising protective spectacles; the most dangerous time is from April to midsummer : once water appears on the ice the danger has passed.

On April 29 Sverdrup arrived at the Taimuir with three dog-teams. Hard and active though sixty-three years old, he made the most favourable impression by his calm bearing, quiet talk and kindly manner. He stayed till May 6, and Norway's greatest holiday, May $4 / 17$, was duly celebrated in his honour. Commander Vilkitski accompanied the return journey some distance with a view to surveying the mouth of the Taimuir River, which had not previously been fixed with precision. An attempt by the commander of the Vaigach, accom. panied by Starokadomski and two sailors, to explore Haffner Gulf, first 
observed by Nansen, proved unlucky, but the gulf was afterwards charted by Lieuts. Lavroff and Evgenoff. Before the middle of May the ice ceased to grow in thickness. During the winter the young ice had gained a thickness of from $150 \mathrm{~cm}$. where covered with snow to $220 \mathrm{~cm}$. where the snow was blown away by the wind. A rise of temperature above the freezing-point was first observed on May 14, but the average temperature for the twenty-four hours was $-3^{\circ} 6^{\circ}$ C. Many snow-buntings, white partridges, and sea-gulls had by this time appeared, and towards the end of May a flock of black geese, while seals appeared on the ice. White bears had approached the ship still earlier. Reindeer were frequently seen on shore, where the snow was melting fast, and the babbling of brooks was heard everywhere.

It had been arranged that the trader Begicheff, who had served in the Zaria Expedition of 1900-1902, should collect and bring to the Eclipse's winter quarters a herd of reindeer to assist in the transport of the shore party to Golchika on the Yenesei, whence the men were to go up-river to Krasnoyarsk and on to Petrograd by rail. Begicheff arrived on June 22 with six hundred and fifty reindeer, part belonging to the Samoyede drivers, while four hundred and thirty-five were for the service of the expedition. The party started on July 2. One of the last visits ashore from the Taimuir was made by the Commander at the end of June and led to the discovery of the tusks and part of the skull of a mammoth, sticking out of the soil, but it was impossible to carry out an excavation.

On the Vaigach the engines were tested on July 3. The ice was thawing rapidly $-3-4 \mathrm{~cm}$. daily. On the night of July $8-9$ the ice-field surrounding the Taimuir executed a turn of several degrees, and a large space of open water appeared under the land. From that time the ship moved slowly with the ice. field in various directions, chiefly to the south-west. On July I5 an attempt was made to force a way through the ice, but this was still too much packed round the ship. A drift shorewards set in while the surrounding ice was packing and breaking up. On July 26 a new attempt was made as new leads were forming. At length an east wind got up, which loosened the ice and permitted some progress to be made, and on July 28 the ships issued into clear water near the mouth of the Taimuir. Proceeding on with a soft stern wind blowing, the voyagers sighted several islands. Soundings were taken regularly, but after they had fallen from I 9 to $10 \frac{1}{2}$ fathoms the Taimuir suddenly bumped on a rock and stuck fast. Water began to come in rather freely, the wind was rising and threatening to bring ice along, and the ship continued to bump on the rocks. By the help of the Vaigach, however, after the discharge of one hundred and sixty tons of fresh water, the ship was successfully got off by great exertions. This day thunder - a rare occurrence in high latitudes-was heard, passing overhead from the westward accompanied by torrents of rain. For several days the ships lay near the Vilkitski group of islands and repaired the damage. To the west the sea was covered with closely packed ice. The Eclipse, which had got clear on July 28 and steamed to Port Dickson to load coal for the expedition, was stopped by a large ice-field 8 miles south of the Scott-Hansen islands, but arrived at Port Dickson on August 3. On August 13 the ice-breakers were forcing the ice in the narrow Fram Straits, having found the passages among the islands of the Nordenskiöld Archipelago iceblocked, and having been detained by adverse winds, with dull and foggy weather. At length, on August I4, the ships by much hard work got clear of the archipelago and steamed on in an open sea among scattered ice. On the I 5th Cape Wilda, the winter quarters of the Eclipse, was passed, and next 
day this vessel joined the ice-breakers and supplied them with coal, afterwards starting to explore Uedineniye Island, and so complete the search for the missing expeditions, of which still no trace could be found. The Eclipse ran aground on the return, but was got off by jettisoning coal. At Dickson Island the Taimuir and Vaigach found the wireless station well advanced. On August 2I news was received of the safe arrival of the shore party at Golchika, whither the Vaigach was sent to bring them on and so save the delay of waiting for a river steamer. In the Kara Sea no ice was encountered, and the ice-breakers safely passed through Yugor Strait, the Eclipse choosing the way of the Iron-gates. On September I all three ships lay off Kanin Nos, and on the 4th reached Archangel and met with a ceremonious reception.

A large mass of meteorological, hydrographical, and biological observations was brought back by the expedition, but the war has delayed their elaboration.

\section{GEOGRAPHY AT THE BRITISH ASSOCIATION}

$\mathrm{T}^{\mathrm{m}}$

$\mathrm{HE}$ meeting of the British Association at Bournemouth in September created considerable interest, as it was occupied to a great extent with matters arising out of the war. In Section $E$ this was particularly the case, and many of the papers read dealt with questions either directly or indirectly connected with the war or with the subsequent peace. At almost every meeting of the Section there was a large attendance. Prof. L. W. Lyde occupied the Presidential chair. The Vice-presidents were Mr. G. G. Chisholm, Prof. H. J. Fleure, Sir T. H. Holdich, Dr. Marion Newbigin, and Mr. E. A. Reeves. Mr. J. McFarlane acted as Recorder, and Mr. C. B. Fawcett and Mr. J. Scattergood as Secretaries.

The President's address on "The International Rivers of Europe" was read at the opening meeting of the Section on September 9. It is reported in full in the November number of the Geographical fournal.

Mr. R. Campbell Thompson followed with an account of some excavations which he had made at Abu Shahrain (the ancient Eridu), about 100 miles west-north-west of Basra. $\mathrm{He}$ believed that the excavations made there showed that, in addition to the Semites in the north of ancient Babylonia and the Sumerians in the south, a third people of the same stock as the peoples of Anau and Elam were established in this district of Southern Babylonia in very early times. Mr. Thompson concluded with some account of modern irrigation and the manners and customs of the inhabitants.

An interesting paper by Mr. C. B. Fawcett on the geographical position and site of Bournemouth concluded the morning's meeting. Bournemouth, Mr. Fawcett explained, is built on a low wedge-shaped plateau between the Stour Valley and Bournemouth Bay. This plateau is formed of unconsolidated materials, mainly Tertiary sands and gravels. The bay is the axial valley of the Hampshire Basin, and the minor surface features are a result of this position and the physical history of the region. The depression of the basin let in the sea to produce the cliffs, and lowered the base-level of the small streams which have since cut out the chines. It also produced the sand-beach. The position of the town on the south coast 100 miles from London was a prime factor in its development. It was beyond the reach of the cheap tripper, but within easy reach of those who intended to stay for 